\title{
Pengaruh Variasi Arus dan Waktu terhadap Pembuatan Serbuk Timah Putih (Sn) melalui Proses Elektrodeposisi
}

\section{The Effect of Variations in Current and Time to Manufacture Powder Tin (Sn) via Electrodeposition Process}

\author{
R. Henny Mulyani ${ }^{1, *}$, Yuliani Carisca Tanjung ${ }^{1}$, dan Djoko Hadi Prajitno ${ }^{2}$ \\ ${ }^{1}$ Jurusan Teknik Metalurgi, Universitas Jenderal Achmad Yani \\ Jalan Jend. Gatot Subroto Tromol POS 807 (PINDAD) Bandung, Indonesia. \\ ${ }^{2}$ Badan Tenaga Nuklir Nasional, Pusat Sains \& Teknologi Nuklir Terapan \\ Jl. Taman Sari No. 71 Bandung 40132, Indonesia.
}

DOI: https://doi.org/10.26874/jkk.v2i1.21

Received: 22 April 2019, Revised: 13 May 2019, Accepted: 31 May 2019, Online: 31 May 2019

\begin{abstract}
Abstrak
Pembuatan serbuk metalurgi melalui proses elektrolisa, sehingga terjadi fenomena pengendapan pada katoda. proses elektrolisa menghasilkan kemurnian tinggi akan tetapi banyaknya senyawa yang ikut terurai akan mempengaruhi kemurniannya. Pembuatan serbuk timah putih (Sn) dilakukan dengan memvariasikan besar arus (5 A, 6 A, dan 7 A) dan waktu proses (20 menit, 25 menit dan 30 menit) dengan variabel tetap temperatur $50{ }^{\circ} \mathrm{C}$ dan konsentrasi larutan $0,01 \mathrm{M}$. Elektroda yang digunakan yaitu stainless steel 304 sebagai katoda dan timah putih (Sn) sebagai anoda. Serbuk timah putih (Sn) yang dihasilkan mencapai $80 \%$, efisiensi arus yang paling diperoleh dari arus 6 A dengan waktu 20 menit dan konsumsi energi yang paling rendah diperoleh dari arus 5 A dengan waktu 20, 25 dan 30 menit yaitu 4,6 KWH/kg Sn. Dari hasil yang diperoleh diharapkan dapat menjadi bahan pertimbangan dalam memproduksi serbuk timah putih (Sn).
\end{abstract}

Kata kunci: Timah putih (Sn), Metalurgi serbuk, Elektrolisa.

\begin{abstract}
Manufacture of powder metallurgy through the process of electrolysis, resulting in the phenomenon of deposition on the cathode. Electrolysis process produces high purity but many compounds decompose participating will affect its purity. Pulverizing tin $(\mathrm{Sn})$ is done by varying the amount of current $(5 \mathrm{~A}, 6$ $A$ and $7 \mathrm{~A}$ ) and processing time (20 minutes, 25 minutes and 30 minutes) with variable fixed temperature of $50^{\circ} \mathrm{C}$ and solution concentration of $0.01 \mathrm{M}$. Electrode used is stainless steel 304 as the cathode and tin $(\mathrm{Sn})$ as the anode. Powder tin (Sn) generated reaches $80 \%$, the most current efficiency is obtained from the current $6 \mathrm{~A}$ with a time of 20 minutes and the lowest energy consumption derived from the current of $5 \mathrm{~A}$ at 20,25 and 30 minutes at $4.6 \mathrm{KWH} / \mathrm{kg} \mathrm{Sn}$. From the results obtained are expected to be a material consideration in producing powder tin (Sn).
\end{abstract}

Keywords: Stannum, Powder metallurgy, Electrolysis. 


\section{Pendahuluan}

Serbuk metal saat ini banyak digunakan di berbagai bahan untuk pembuatan sebuah komponen seperti gera roda, cincin piston, gear, alat bedah dan lain-lain, karena serbuk metal mudah dibentuk maupun dicetak.

Teknik metalurgi serbuk adalah salah satu alternative proses produksi suatu komponen, dimana proses ini melibatkan pemadatan serbuk logam kedalam bentuk yang inginkan dengan cara penekanan dalam suatu cetakan sebagai proses lanjutan pembentukan komponen.

Logam yang paling umum digunakan dalam serbuk metal adalah besi, aluminium, tembaga, timah, nikel titanium, dan logam tahan panas. Untuk logam seperti kuningan, perunggu, baja dan baja tahan karat akan melalui proses campuran dengan sumber dari logam padat dan campuran, bijih, garam dan campuran lainnya.

Ada beberapa teknik pembuatan serbuk diantaranya adalah dengan cara mekanik (Mechanical atau Pulverization), cara kimia (Chemical), cara elektrolisa (Electrolytic Deposition) dan cara atomisasi (Atomization), maka dalam penulisan yang akan dibahas yaitu mengenai proses pembuatan serbuk timah putih (Sn) secara elektrolisa.

Serbuk timah akan terbentuk pada proses elektrolisa yang disebabkan oleh pengendapan pada elektroda dari anoda dan larutan elektrolit. Beberapa keunggulan proses elektrolisa yaitu, masalah korosi relatif rendah, kadar kemurnian logam yang dihasilkan relatif tinggi, proses umumnya dilakukan pada temperatur kamar (bila dengan pemanasan temperatur yang digunakan tidak terlalu tinggi), sehingga konsumsi energi logam serbuk akan lebih rendah dan proses bisa dilakukan pada skala kecil dan baru kemudian dapat dikembangkan sesuai kebutuhan.

Karakteristik serbuk dilakukan untuk mengetahui sifat serbuk logam selama proses pembuatan produk melalui kompaksi dan penyinteran serta pengaruh terhadap sifat produk akhir. Karakter serbuk akan menentukan langkah proses pembuatan produk dan kualitas produk yang diproduksi. Sifat serbuk yang penting diantaranya adalah ukuran dan distribusi serbuk serta terbentuk serbuk.

Elektrolisa adalah penguraian suatu larutan elektrolit secara kimiawi oleh arus listrik yang dialirkan melaluinya.Merupakan proses kimia yang mengubah energi listrik menjadi energi kimia. Dalam sel elektrolisa terjadinya reaksi kimia karena adanya energi dari luar dalam bentuk potensial atau arus listrik. Reaksi yang berlangsung pada sel elektrolisa adalah reaksi yang tergolong dalam reaksi redoks.

Komponen yang terpenting dari proses elektrolisa ini adalah elektroda dan elektrolit. Elektrolit dapat berupa larutan berupa asam, basa, atau garam, dapat pula leburan garam halida atau leburan oksida. Inti dari proses elektrolisa adalah reaksi Redoks (reduksi-oksidasi). Reaksi reduksi adalah reaksi yang pada pelaksanaannya membutuhkan elektron sedangkan reaksi oksidasi merupakan suatu reaksi kimia yang melepaskan elektron.

Pada elektrolisa, katoda merupakan kutub negatif dan anoda merupakan kutub positif. Pada katoda akan terjadi reaksi reduksi dan pada anoda terjadi reaksi oksidasi. Elektroda akan disebut sebagai anoda bila reaksi oksidasi terjadi padanya. Sebaliknya, elektroda akan disebut katoda bila reaksi reduksi padanya.

Sel elektrolisa tersusun dari elektrodaelektroda yang dicelupkan dalam suatu elektrolit. Elektroda yang dihubungkan dengan kutub negatif disebut katoda (tempat terjadi reduksi) sedangkan elektroda yang dihubungkan dengan kutub positif disebut anoda (tempat terjadi oksidasi).

Pengendapan timah putih dilakukan dengan mengalirkan arus searah dari sumber pada sel elektrolisa sehingga logam timah putih mengendap di katoda. Reaksi utama yang terjadi pada proses pengendapan timah putih adalah sebagai berikut:

$$
\begin{aligned}
& \mathrm{SnSO}_{4}(a q) \rightleftharpoons \mathrm{Sn}^{2+}(a q)+\mathrm{SO}_{4}{ }^{2-}(a q) \\
& \text { Pada katoda: } \mathrm{Sn}^{2+}+2 e^{-} \rightarrow \operatorname{Sn}(s) \\
& 2 \mathrm{H}^{+}+2 e^{-} \rightarrow \mathrm{H}_{2}(\mathrm{~g})
\end{aligned}
$$

Umumnya deret volta yang sering dipakai adalah:

\section{Li K Ba Sr Ca Na Mg Al Mn Zn Cr Fe Cd Co Ni Sn Pb H Sb Bi Cu Hg Ag Pt Au}

Pada deret volta, unsur logam dengan potensial elektroda lebih negatif ditempatkan di bagian kiri, sedangkan unsur dengan potensial elektroda yang lebih positif ditempatkan di bagian kanan.

Semakin ke kiri kedudukan suatu logam dalam deret tersebut, maka logam semakin reaktif (semakin mudah melepas elektron), tetapi sebaliknya semakin ke kanan maka kedudukan suatu logam dalam deret tersebut akan semakin kurang reaktif (semakin sulit melepas elektron). 


\section{Metode Penelitian}

\subsection{Bahan dan Alat}

Alat yang digunakan untuk proses pembuatan serbuk Sn pada penelitian ini yaitu neraca analitik, gelas kimia, gelas ukur, pipet ukur, spatula, labu ukur, batang pengaduk, botol semprot, alat pengering, mesin sieve dan ampere meter.

Bahan yang digunakan yaitu stainless steel 304, timah putih, larutan $\mathrm{HCl}$, larutan $\mathrm{NaOH}$, larutan $\mathrm{H}_{2} \mathrm{SO}_{4}$, serbuk $\mathrm{SnSO}_{4}$, dan aquades.

\subsection{Prosedur Penelitian}

Larutan elektrolit $\mathrm{SnSO}_{4}$ 0,1 M dimasukkan kedalam gelas kimia kemudian rangkai preparasi. Percobaan dilakukan dengan memvariasikan arus agar diperoleh hasil serbuk yang optimal dimulai dari $5 \mathrm{~A}, 6 \mathrm{~A}$ dan $7 \mathrm{~A}$ dengan masing-masing waktu 20 menit, 25 menit dan 30 menit. Proses elektrolisa dilakukan dengan memberikan arus dari luar yaitu sumber arus searah yang dihubungkan secara seri dengan amperemeter. Setiap proses elektrolisa berlangsung pada temperatur $50^{\circ} \mathrm{C}$, karena pada temperatur ini akan mempercepat proses pembentukan serbuk pada katoda. Setelah proses selesai katoda diangkat, dibilas dengan aquades, dikeringkan di udara terbuka dan menggunakan alat pengering. Selanjutnya dilepaskan serbuk dari katoda, untuk mendapatkan berat yang benar maka serbuk yang dihasilkan harus benar-benar kering sebelum ditimbang sebagai berat praktek. Rangkaian proses elektrolisis tersebut diperlihatkan pada Gambar 1.

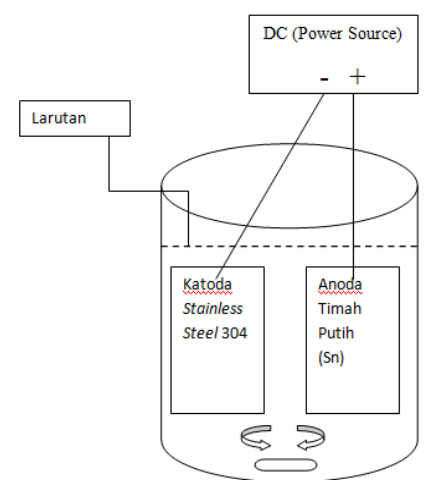

Gambar 1. Rangkaian proses elektrolisa

\subsection{Karakterisasi Serbuk}

Sampel serbuk Sn (timah putih) kemudian dilakukan pemeriksaan visual yang bertujuan untuk mengetahui tampak rupa serbuk seperti warna, kerataan dan kehalusan. Pemeriksaan visual dilakukan dengan mata telanjang.
Kemudian dilanjutkan dengan pengujian XRD, SEM dan Microscopy.

\section{Hasil dan Diskusi}

\subsection{Proses Elektrolisa}

Pengaruh variasi arus dan waktu terhadap berat serbuk yang dihasilkan saat proses diperlihatkan pada Gambar 2 dan 3.

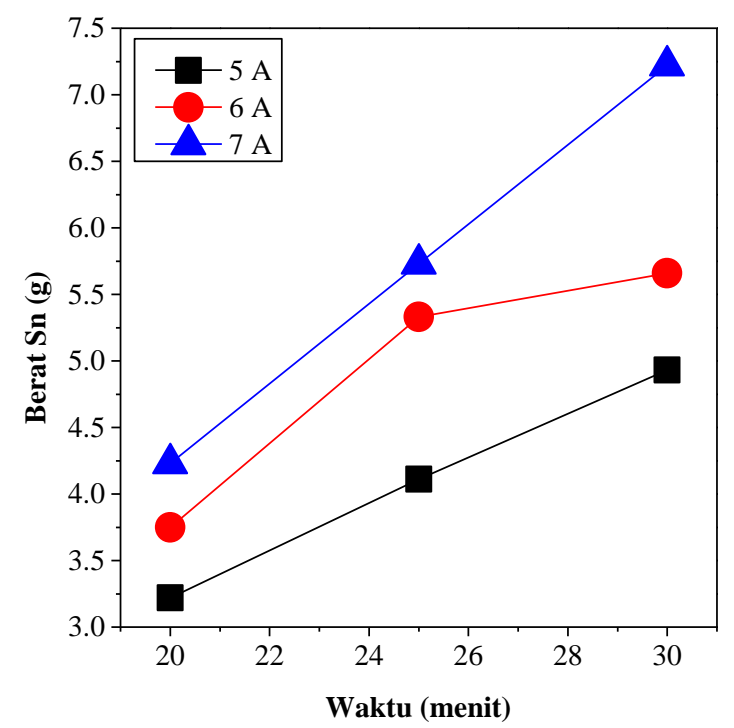

Gambar 2. Grafik Pengaruh Waktu Terhadap Berat

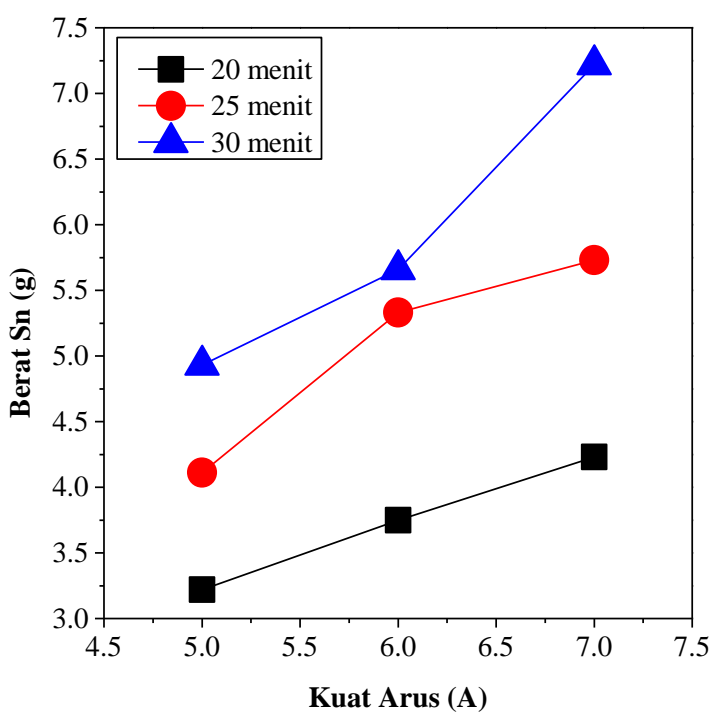

Gambar 3. Grafik Pengaruh Arus Terhadap Berat

Pada Gambar 2 diperlihatkan pengaruh waktu terhadap berat serbuk timah putih (Sn) yang dihasilkan melalui proses elektrolisa. Di mana, pada variable arus $5 \mathrm{~A}$ berat serbuk timah putih (Sn) dengan waktu 20 menit, 25 menit dan 30 menit mengalami pertambahan berat yang konstan dengan selisih pertambahan berat $\pm 0,8$ gram. Untuk variabel arus 6 A berat serbuk timah putih (Sn) dengan perbedaan waktu yang sama juga 
mengalami pertambahan berat namun kurang kurang konstan dapat dilihat pada waktu 25 menit serbuk yang terbentuk yaitu 5,33 gram kemudian pada waktu 30 menit serbuk yang terbentuk yaitu 5,66 selisih keduanya sangat kecil dibandingkan waktu 20 menit dan 25 menit. Kemudian untuk variabel 7 A berat serbuk timah putih (Sn) mengalami pertambahan berat yang konstan dengan selisih berat lebih besar \pm 1 gram pada setiap pertambahan waktu, dapat dilihat untuk variabel 7 A garis menunjukkan kemiringan yang lebih tinggi.

Pada Gambar 3 diperlihatkan pengaruh arus terhadap berat serbuk timah putih (Sn) yang dihasilkan melalui proses elektrolisa. Pada waktu 20 menit mengalami pertambahan berat yang konstan di semua variable arus dengan selisih berat $\pm 0,5$ gram. Pada waktu 25 menit garis grafik menunjukkan pertambahan berat serbuk tidak konstan jika dibandingankan dengan waktu 20 menit. Hal ini, dapat dilihat selisih pertambahan berat pada arus $6 \mathrm{~A}$ dan $7 \mathrm{~A}$ hanya bertambah \pm 0,4 gram sedangkan pada arus $5 \mathrm{~A}$ dan $6 \mathrm{~A}$ selisih pertambahan berat \pm 1 gram. Pada waktu 30 menit garis grafik juga menunjukkan pertambahan berat yang tidak konstan namun berat serbuk lebih besar dibandingkan waktu 20 dan 25 menit. Perbedaan peningkatan berat terjadi pada arus 6 A dan 7 A dengan selisih pertambahan berat $\pm 1,5$ gram sedangkan pada arus 5 A dan 6 A selisih pertambahan berat $\pm 0,7$ gram, perbedaan tersebut yang menyebabkan garis grafik tidak konstan.

Pada proses elektrolisa berat serbuk yang dihasilkan dapat dihitung sebelumnya menggunakan hukum faraday sehingga efisiensi berat yang akan dihasilkan dapat diketahui. Pada gambar 4 dipelihatkan diagram perbandingan berat teoritis dan berat aktual serbuk timah putih (Sn). Diagram menunjukan perbedaan tinggi antara berat teoritis dan berat aktual tidak jauh berbeda.

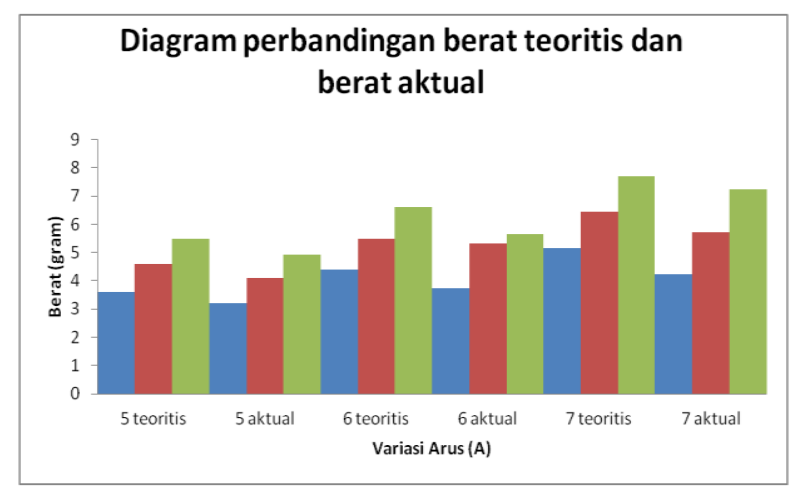

Gambar 4. Perbandingan berat Sn teoritis dan aktual
Pada Gambar 5 diperlihatkan pengaruh waktu terhadap efisiensi arus. Untuk arus 5 A dengan waktu 20 menit, 25 dan 30 menit efisiensi arus konstan mendatar dikarena hasil efisiensi untuk ketiga waktu tersebut hampir sama yaitu 89, 89,3 dan 89,6 \%. Untuk arus 6 A garis grafik menunjukkan tidak konstans dikarenakan garis grafik menunjukkan penaikan efisiensi kemudian penurunan kembali hal ini dikarenakan hasil berat serbuk aktual dengan berat serbuk teori menunjukkan $96 \%$ pada waktu 25 menit sedangkan pada waktu 30 efisiensi menunjukkan $85,7 \%$. Sedangkan untuk arus 7 A efisiensi pada ketiga beda waktu menunjukkan peningkatan efisiensi yang konstans sehingga garis grafik mengarah ke atas.

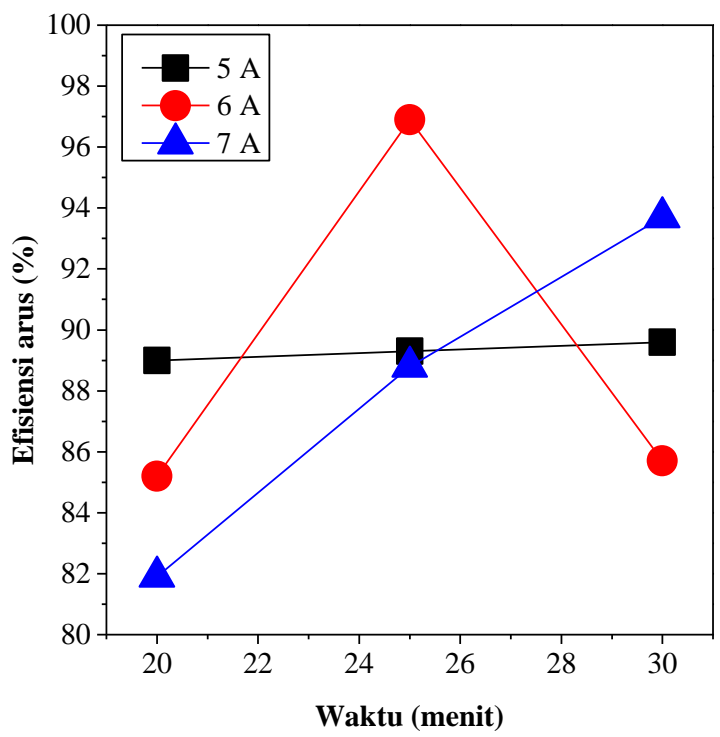

Gambar 5. Pengaruh waktu elektrolisis terhadap efisiensi arus

Pada Gambar 6 menunjukan pengaruh waktu terhadap efisiensi arus. Untuk waktu 20 menit pada ketiga variable arus efisiensi menunjukkan penurunan secara konstans, sedangkan untuk waktu 25 menit garis grafik menunjukkan efisiensi mengalami penaikan kemudian menurunan hal ini dikarenakan besar efisiensi pada arus 6 A lebih besar dibandingkan efisiensi pada arus $7 \mathrm{~A}$. untuk waktu 30 menit garis grafik juga menunjukan ketidakkonstanan nilai persen efisiensi, hal ini disebabkan nilai efisiensi pada arus 6A lebih kecil dibandingkan arus $7 \mathrm{~A}$.

Pada proses elektrolisa seluruh energi yang dibutuhkan berasal dari power supply DC dengan arus sebagai penghasil energi serbuk dapat diendapkan pada katoda. Gambar 7 memperlihatkan bagaimana pengaruh besar arus saat proses terhadap konsumsi energi. Pada waktu 20 menit dengan variable arus 5 A, 6 A dan 7 A 
garis grafik menunjukkan peningkatan konsumsi energi. Begitu juga tampak pada waktu 25 menit dengan variasi arus yang sama peningkatan konsumsi lebih besar dibandingkan pada waktu 20 menit. Dan konsumsi energi lebih besar ditunjukkan pada waktu 30 menit.

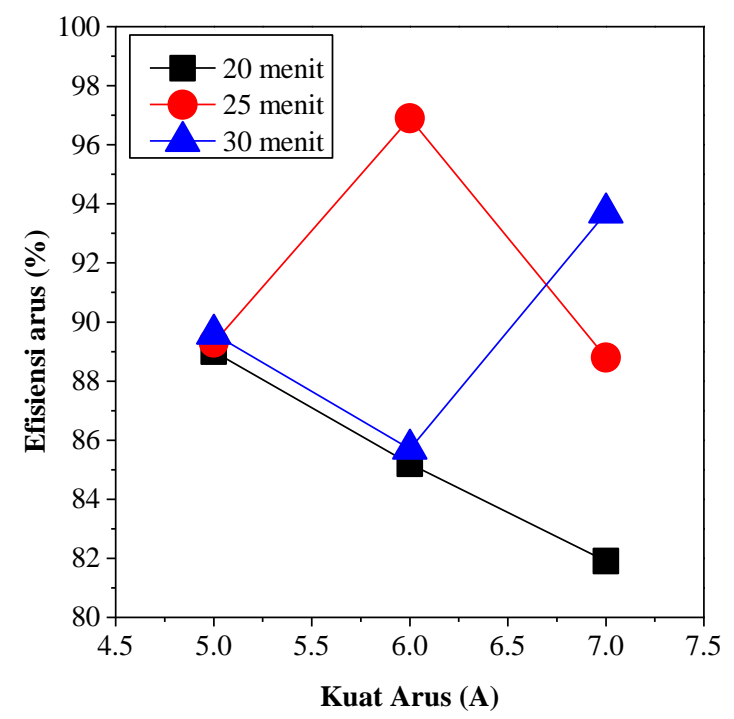

Gambar 6. Pengaruh kuat arus terhadap efisiensi arus

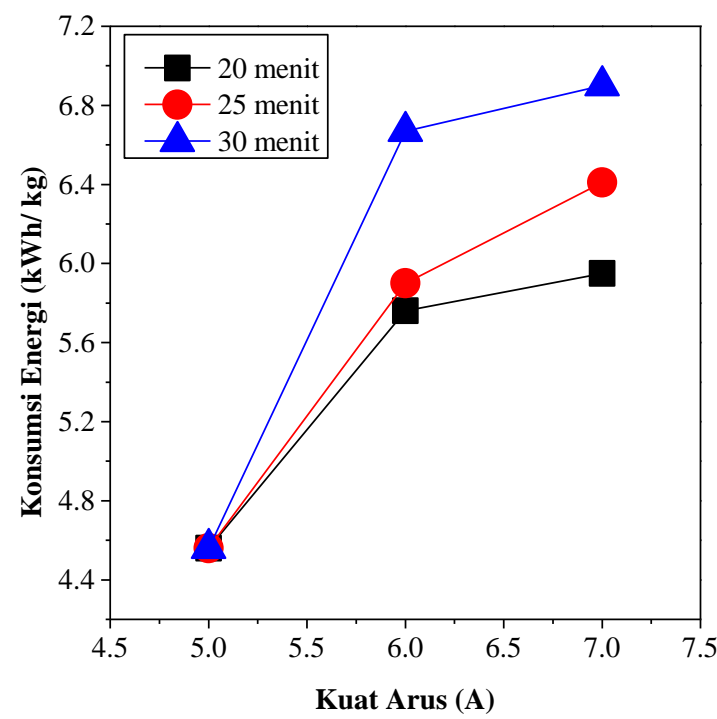

Gambar 7. Pengaruh kuat arus terhadap efisiensi arus

Pada gambar 2 diperlihatkan pengaruh waktu terhadap berat. Dari hasil penimbangan berat serbuk timah putih hasil proses elektrolisa seperti yang ditunjukkan pada gambar 2 bahwa semakin lama waktu proses elektrolisa dengan arus yang dan sebaliknya jika berat aktual semakin menjauh dari berat teori menghasilkan persentase efisiensi yang rendah.

Besar arus yang digunakan sebagai sumber energi menpengaruhi konsumsi energi selama waktu proses. Hal ini ditunjukkan pada gambar 7 tetap maka berat serbuk yang dihasilkan akan mengingkat. Hal ini di sebabkan karena semakin lama waktu proses maka pertumbuhan butir pada katoda serbuk semakin banyak. Peningkatan berat variasi waktu yang berbeda konstans pada arus 5 A dan 7 A, sedangkan pada arus 6 A peningkatan berat tidak konstan. Hal ini, diakibatkan kestabilan pertumbuhan butir saat proses elektrolisa. Berat serbuk timah putih yang dihasilkan pada saat proses elektrolisa juga berhubungan dengan gambar 3 dimana diperlihatkan pengaruh arus terhadap berat serbuk timah hasil proses elektrolisa.

Pengaruh waktu berbanding lurus dengan berat serbuk timah putih sama seperti arus dimana semakin besar arus yang diberikan maka supply energi yang diberikan untuk mereduksi anoda akan semakin berat sehingga kecepatan pertumbuhan butir pada katoda akan semakin banyak. Pada penelitian ini arus 5 A memiliki stabilan yang optimum dibandingkan arus lainnya dikarenakan berat serbuk yang dihasilkan bertambah secara konstan.

Gambar 2 dan 3 menunjukkan berat aktual saat proses, sedangkan sebelum proses berat serbuk dapat diketahui sebagai acuan perbandingan berat. Maka pada gambar 4 di tunjukkan diagram perbandingan berat teoritis dan berat aktual. Dimana, hasil berat keduanya tidak jauh berbeda atau hampir mendekati. Berat teoritis dan berat aktual berhubungan dengan efisiensi arus. Sehingga pada gambar 5 dan 6 di perlihatkan grafik pengaruh waktu terhadap efisiensi arus dan grafik pengaruh arus terhadap efisiensi arus. Seperti yang ditunjukkan pada gambar 2 bahwa semakin lama waktu proses elektrolisa maka berat serbuk yang dihasilkan akan semakin banyak hal ini berpengaruh pada efisiensi arus.

Pada gambar 5 menunjukan semakin lama waktu proses persentase efisiensi arus akan semakin rendah. Selanjutnya untuk gambar 6 menunjukkan pengaruh arus terhadap efisiensi arus semakin besar arus yang digunakan maka efisiensi arus harus akan semakin tinggi. Efisiensi arus berhubungan dengan perbandingan berat teoritis dan aktual dimana jika berat aktual semakin mendekati berat teori maka menghasilkan persentase efisiensi arus yang tinggi

dimana semakin besar arus yang digunakan dengan rentang waktu yang lama maka konsumsi energi akan semakin besar.

Pada proses pembuatan serbuk timah melalui elektrolisa makan dapat disimpulkan bahwa peningkatan berat secara konstan akan terjadi pada 
arus $5 \mathrm{~A}$ dan $7 \mathrm{~A}$, namun untuk konsumsi energi pada arus $7 \mathrm{~A}$ akan membutuh energi lebih banyak dibandingkan dengan arus $5 \mathrm{~A}$.

Proses pembuatan serbuk timah putih melalui elektrolisa menghasilkan reaksi sebagai berikut:

Katoda (-) : $\operatorname{Sn}^{2+}(a q)+2 e^{-} \rightarrow \operatorname{Sn}(s)$

Anoda (+) $: \operatorname{Sn}(s) \rightarrow \mathrm{Sn}^{2+}+2 e^{-}$

Pada larutan elektrolit:

$$
\mathrm{SnSO}_{4}(a q) \rightarrow \mathrm{Sn}^{2+}(a q)+\mathrm{SO}_{4}{ }^{2-}(a q)
$$

Katoda(-): $2 \mathrm{Sn}^{2+}(a q)+4 e^{-} \rightarrow 2 \operatorname{Sn}(s)$ Anoda $(+): 2 \mathrm{H}_{2} \mathrm{O}(l) \rightarrow \mathrm{O}_{2}(g)+4 \mathrm{H}^{+}(a q)+4 e^{-}$

\subsection{Pemeriksaan Visual}

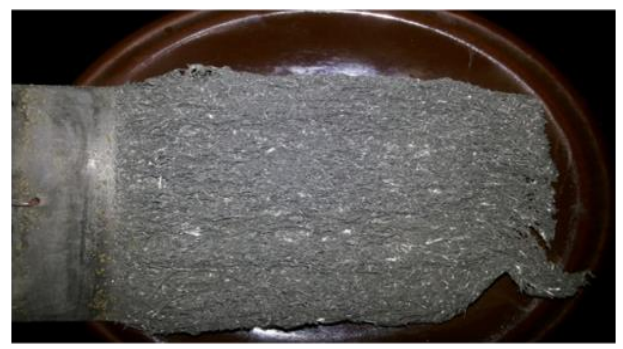

Gambar 8. Tampak Visual Serbuk yang Menempel di Katoda Pembesaran 1x

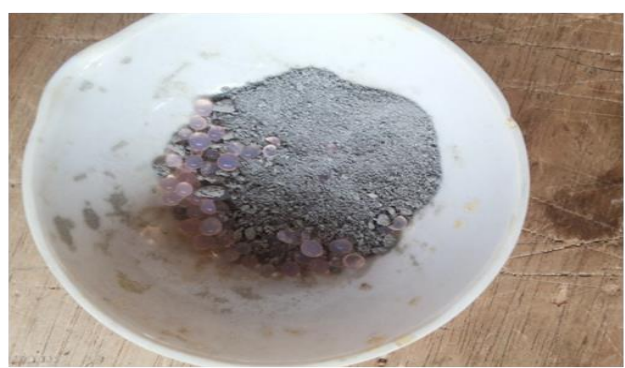

Gambar 9. Tampak Visual Serbuk Setelah di lepaskan dari Katoda Pembesaran 1x

Pemeriksaan visual ditujukan untuk mengetahui warna dan tampak serbuk timah putih setelah proses elektrolisa. Dapat dilihat pada Gambar 8 serbuk timah putih yang masih menempel atau mengedap di katoda tanpa adanya gradasi warna atau perbedaan warna pada setiap bagian. Selanjutnya pada Gambar 9 tampak serbuk timah putih yang telah dilepaskan dari katoda dan dikeringkan tidak terjadi perubahan warna antara serbuk timah putih yang masih menempel dengan katoda sebelumnya.

\subsection{Pemeriksaan Distribusi Besar Butir}

Pada Gambar 10 diperlihatkan grafik nilai distribusi besar butir serbuk timah putih (Sn).
Garis grafik menunjukkan adanya peningkatan nilai besar butir pada setiap penaikan arus dan waktu. Maka semakin besar arus dan lama waktu yang digunakan maka nilai distribusi besar butir akan meningkat.

Pengujian distribusi besar butir dilakukan menggunakan mesin sieve dimana serbuk akan diayakan dengan 10 (sepuluh) saringan dengan ukuran yang berbeda-beda. Nilai distribusi yang paling besar diperoleh dari serbuk timah putih dengan variabel 7 A dan 30 menit dikarenakan berat serbuk timah putih pada variabel ini lebih banyak yaitu 7,22 gram. Sedangkan untuk perolehan nilai distribusi besar butir yang paling kecil diperoleh dari serbuk timah putih dengan variabel 5 A 25 menit dikarenakan berat serbuk timah putih pada variabel ini lebih rendah yaitu 3,38 gram. Dari hasil pengujian ini dapat diperoleh bahwa ukuran terkecil butir serbuk timah putih (Sn) yang dihitung secara manual menggunakan mesin pengayakan adalah 55 mikron.

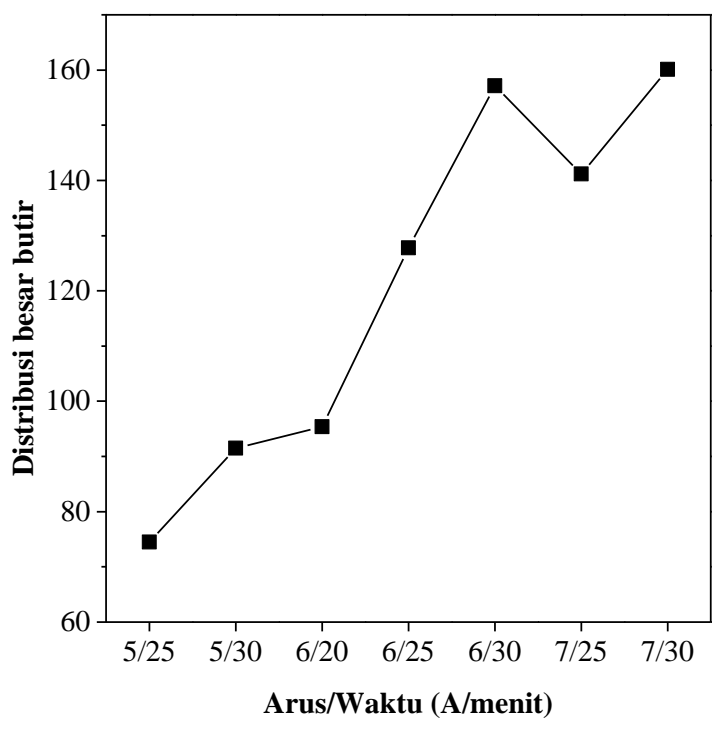

Gambar 10. Pengaruh arus dan waktu terhadap distribusi besar butir serbuk $\mathrm{Sn}$

\subsection{Pengujian XRD}

Sampel uji untuk pengujian XRD di pilih 2 (dua) sampel dari 9 (sembilan) sampel yang ada. Pengujian XRD ditujukan untuk mengetahui senyawa yang ikut terurai dalam proses elektrolisa. Sehingga diperoleh hasil dari XRD pada Gambar 11.

Gambar 11 memperlihatkan hasil XRD pada sampel uji variabel arus 5 A dan waktu 20 menit. Tanda " $x$ " menunjukkan adanya senyawa $\mathrm{Sn}_{3} \mathrm{OSO}_{4}(\mathrm{OH})_{2}$ dengan persentase $2 \%-12 \%$. Selanjutnya tanda "o" mengindensikan adanya 
unsur Sn sebagai serbuk timah putih dengan persentase hampir mencapai $90 \%$.

Gambar 12 diperlihatkan hasil XRD pada sampel uji dengan arus yang lebih besar dan waktu yang lebih lama yaitu $\mathrm{A}=7 \mathrm{~A}$ dan $\mathrm{t}=30$ menit. Hasil pengujian hampir serupa dengan sampel uji 1 yaitu adanya senyawa $\mathrm{Sn}_{3} \mathrm{OSO}_{4}(\mathrm{OH})_{2}$ dengan persentase $2 \%$ hingga $12 \%$ dan Sn (timah putih) dengan persentase hampir mencapai $90 \%$.

Pengambilan sampel untuk pengujian XRD didasari dikarena dari data hasil proses elektolisa pada arus 5 A dan 7 A menghasilkan berat, efisiensi arus dan konsumsi energi yang konstans. Pada gambar 4.8 dan 4.9 diperlihatkan senyawa yang dapat identifikasi yaitu $\mathrm{Sn}_{3} \mathrm{OSO}_{4}(\mathrm{OH})_{2}$ senyawa ini berada pasa kedua sampel dengan persentase $2 \%-12 \%$. Hal ini disebabkan sampel tidak melalui proses pengeringan yang cukup atau dapat dikatakan sampel masih dalam keadaan lembab. $\mathrm{Sn}_{3} \mathrm{OSO}_{4}(\mathrm{OH})_{2}$ berasal dari penguraian reaksi di larutan elektrolit. Melalui persamaan berikut :

$$
\begin{aligned}
& \mathrm{Sn}^{2+}+3 \mathrm{OH}^{-} \rightarrow \mathrm{Sn}(\mathrm{OH})_{3}{ }^{-} \\
& 6 \mathrm{Sn}(\mathrm{OH})_{3}^{-} \rightarrow \mathrm{Sn}_{6} \mathrm{O}_{4}(\mathrm{OH})_{4}+4 \mathrm{H}_{2} \mathrm{O}+6 \mathrm{OH}
\end{aligned}
$$

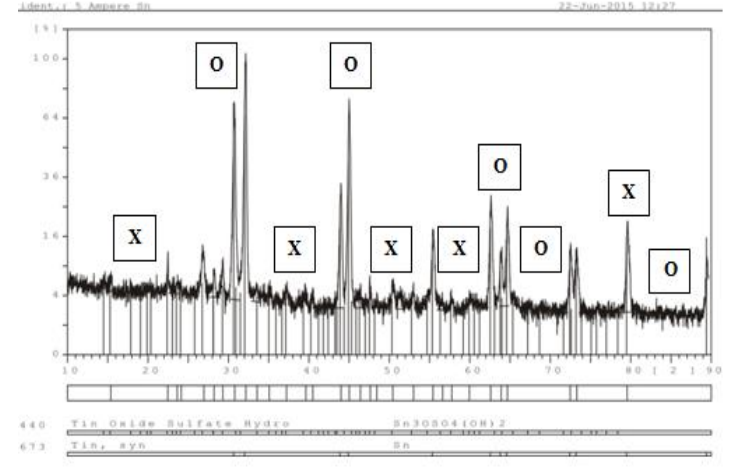

Gambar 11. Hasil XRD serbuk timah yang dihasilkan menggunakan arus 5 A selama 20 menit

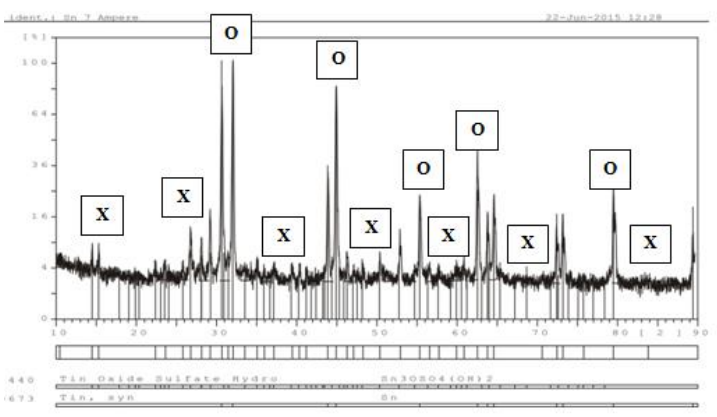

Gambar 12. Hasil XRD serbuk timah yang dihasilkan menggunakan arus 7 A selama 30 menit

\subsection{Pengujian Struktur Mikro}

Struktur mikro dilakukan untuk mengkarakterisasi serbuk timah putih (Sn) yang dihasilkan, data tersebut akan menjadi data awal bentuk partikel atau bentuk butir dari serbuk timah putih (Sn). Pada Gambar 13, terlihat bahwa serbuk hasil sintesis dengan arus 5 A dan waktu 20, 25, atau 30 menit memiliki bentuk irregular/ tidak beraturan. Serbuk timah hasil sintesis dengan arus 6 A dan waktu 20, 25, atau 30 menit memiliki bentuk irregular yang lebih kasar dan menyebar dipermukaan. Sedangkan serbuk timah hasil sintesis dengan arus 7 A dan waktu 20, 25, atau 30 menit memiliki bentuk butir irregular yang lebih besar dan halus.

Semakin besar arus dan waktu yang ditambahkan maka akan memperhalus ukuran butir serbuk disebabkan perpindahan ion dari anoda ke katoda atau dari larutan elektrolit ke katoda memiliki energi yang lebih besar sehingga laju difusi antar partikel serbuk semakin cepat dan ukuran butir akan semakin besar. Butir-butir yang saling berkontak berdifusi membentuk butir baru dan ukuran yang lebih besar.

\subsection{Pengujian SEM-EDS}

Berdasarkan hasil pengujian SEM (Gambar 14) terlihat bahwa butir serbuk timah putih cenderung menyatu hal ini diakibatkannya sifat lunak yang dimiliki oleh timah putih. Secara keseluruhan butir berbentuk irregular dengan ukuran butir terkecil dapat mencapai 20 mikron.

Semakin rendah arus dan lama waktu proses maka butir satu dengan butir yang lainnya akan semakin menyatu, hal tersebut terjadi karena kecepatan difusi yang lambat. Sehingga pada gambar struktur mikro terlihat jarak antar partikel sangat dekat untuk arus dan lama waktu proses yang lebih kecil.

Arus yang lebih besar membuat percepatan pertumbuhan lebih besar dibandingkan pengintian sehingga butir-butir yang saling berkontak berdifusi membentuk butir baru dengan ukuran yang lebih besar.

Citra SEM dan spektrum EDS untuk serbuk timah yang dihasilkan melalui elektrodeposisi selama 20 menit dengan arus 5, 6, atau 7 A diperlihatkan pada Gambar 15. Berdasarkan Gambar 15, persentasi kemurnian berbanding lurus dengan kuat arus yang digunakan pada waktu yang sama. 

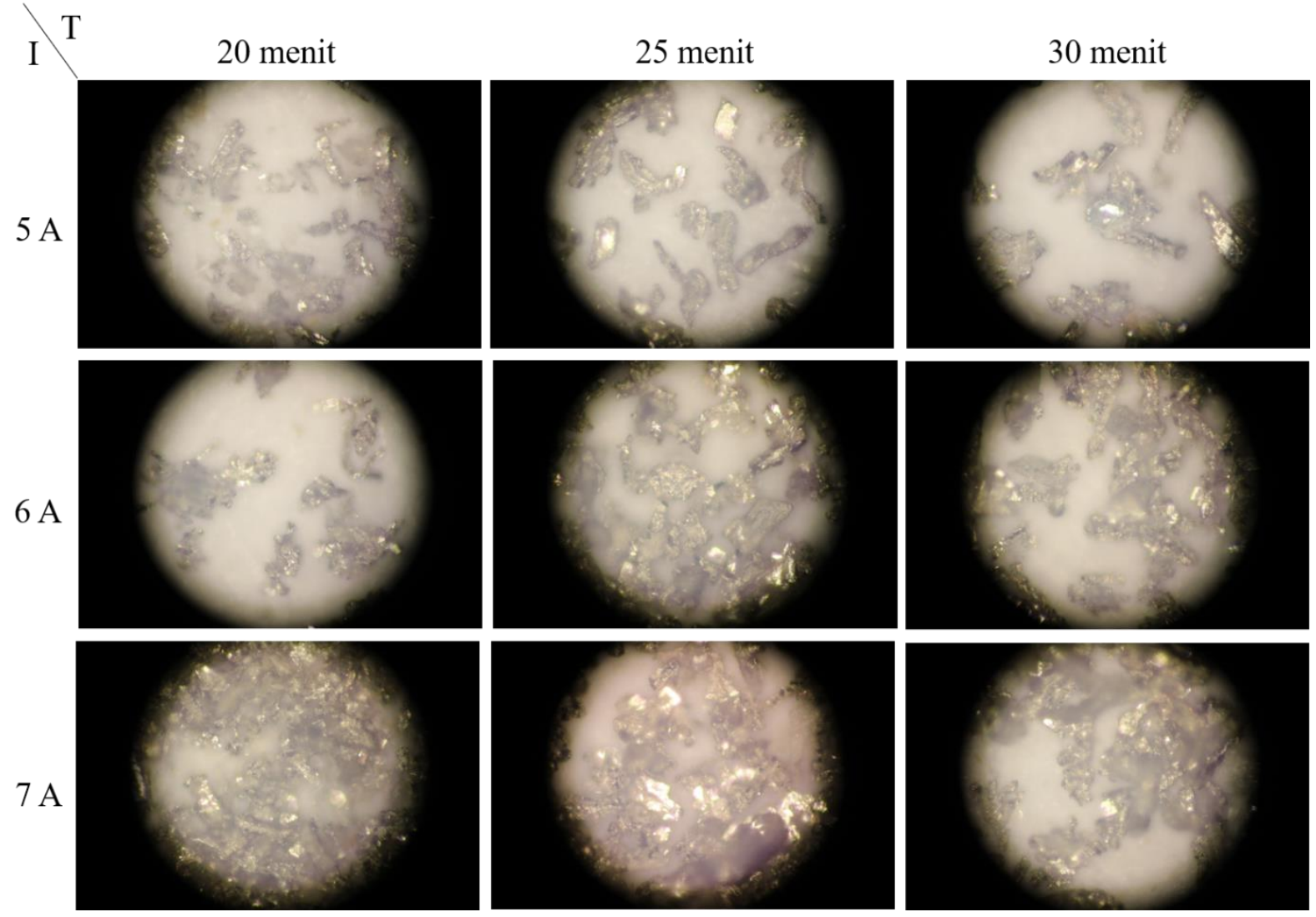

Gambar 13. Struktur mikro serbuk timah hasil sintesis melalui metode elektrodeposisi dengan variasi arus $(5,6$, dan 7 A) dan waktu (20, 25, dan 30 menit)

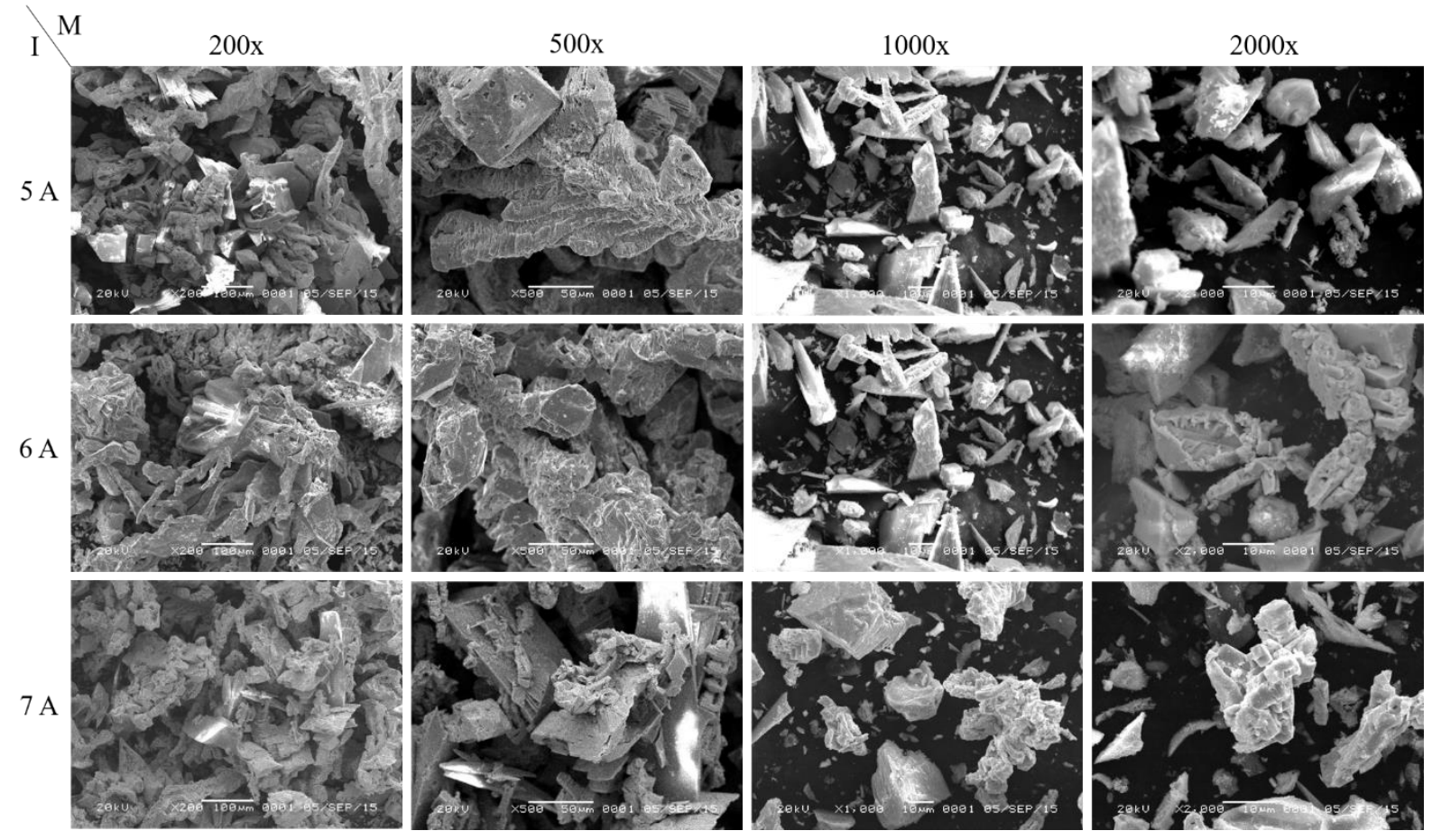

Gambar 14. Citra SEM dengan berbagai perbesaran (M) dari serbuk Sn hasil sintesis melalui metode elektrodeposisi $\mathrm{SnSO}_{4}$ dengan kuat arus (I) $5 \mathrm{~A}, 6 \mathrm{~A}$, atau 7 A selama 20 menit 


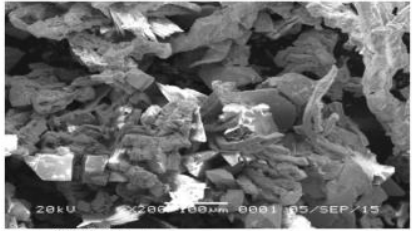

(a)

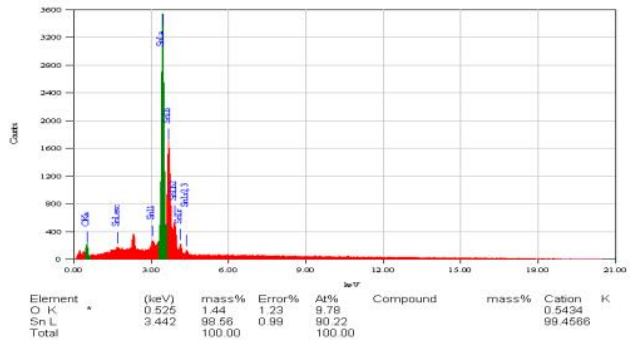

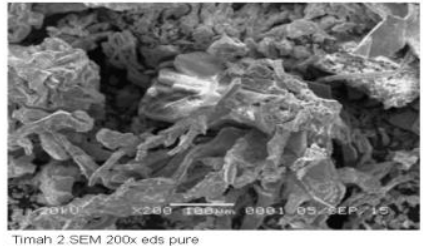

(b)

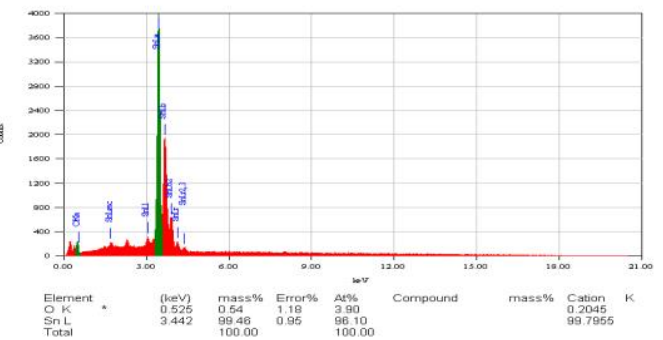

(c)
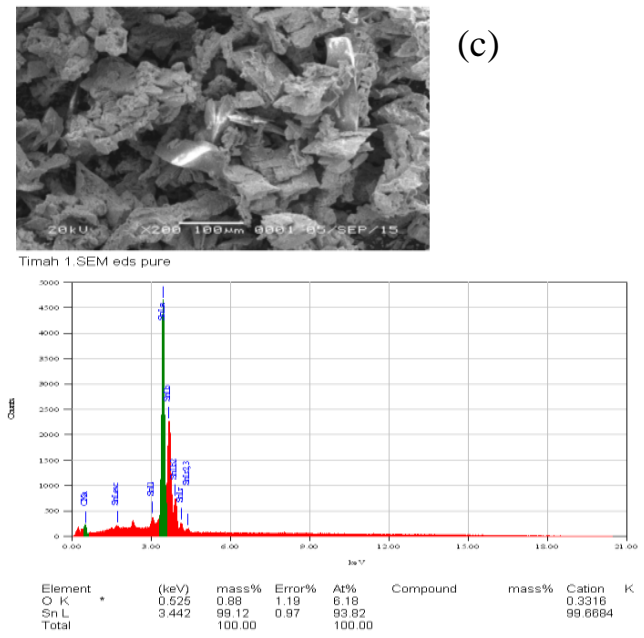

Gambar 15. Citra SEM dan spektrum EDS untuk serbuk timah yang dihasilkan dengan variasi arus selama 20 menit: a) $5 \mathrm{~A}$; b) $6 \mathrm{~A}$; dan c) $7 \mathrm{~A}$

\section{Kesimpulan}

Serbuk yang memiliki kehalusan butir yang optimum, peningkatan berat serbuk yang konstans yaitu $\pm 0,8$ gram , konsumsi energi yang terlalu tinggi yaitu $4,56 \mathrm{KWH} / \mathrm{Kg}$ dan efisiensi arus rendah dengan rata $89 \%$ yaitu serbuk timah putih (Sn) dengan variabel arus 5 A dengan waktu 20 menit 25 menit atau 30 menit.

Dari hasil pengayakan nilai distribusi yang paling rendah diperoleh dari arus 5 A yaitu dengan rata-rata 83,006 sedangkan nilai distribusi yang paling tinggi diperoleh dari arus 7 A dengan ratarata 150,626 . Semua sampel serbuk timah putih (Sn) dapat tersaring hingga ukuran 55 mikron.

Dari hasil struktur mikro dan pengujian SEM didapatkan bentuk secara keseluruhan adalah berbentuk irregular. Dari hasil struktur mikro SEM ukuran butir terkecil serbuk timah putih (Sn) berada pada \pm 20 mikron.

Dari hasil pengujian EDS dapat ditarik kesimpulan sebagai berikut :Pengaruh besar arus terhadap persentase kemurnian serbuk yaitu serbuk timah putih (Sn) dengan arus 7 A dan 6 A memiliki kemurnian $99 \%$ sedangkan untuk 5 A memiliki persentase kemurnian $98 \%$. Pengaruh besar arus terhadap ukuran butir, yaitu arus yang lebih besar membuat percepatan pertumbuhan lebih besar dibandingkan pengintian sehingga butir-butir yang saling berkontak berdifusi membentuk butir baru dengan ukuran yang lebih besar.

\section{Ucapan Terima Kasih}

Penulis mengucapkan terima kasih kepada Jurusan Teknik Metalurgi dan BATAN (Badan Tenaga Nuklir Nasional) atas fasilitas yang telah digunakan pada penelitian ini.

\section{Daftar Pustaka}

[1] S.-S. Chen. J-H. Lee. Effects of Process Parameter in synthesizing Sn nanoparticles 
via chemical reduction, Electron . Mater Lett. 8 (2012) 53-58.

[2] A. Lal. H. Bleuler, R. Wuthrich. Fabrication of metallic nanoparticles by electrochemical discharges. Electrochem. Common. 10 (2008) 488-491.

[3] G. Saito, Et Al. Advanced Powder Technology 25 (2014) 1038-1042.

[4] Lei Xu, Jinhui Peng, Hailong Bai, C. Srinivasakannan, Libo Zhang, Qingtian $\mathrm{Wu}$, Zhaohui Hana, Shenghui Guo, Shaohua Ju dan Li Yang. "Application of Microwave Melting for the Recovery of Tin Powder", (2017).

[5] http://www.reade.com/products/tin-snmetal-powder-granule-flake (diakses pada tanggal 9 desember 2017 Pukul 08.15 WIB).
[6] A. Collazo, R. Figueroa, X.R. Nóvoa dan C. Pérez. "Electrodeposition of tin from a sulphate bath", (2015).

[7] http://fathul-ilmi.blogspot.com /2013/09/ teori-dasar-x-ray-diffraction-xrd.html (di akses pada tanggal 9 September 2015 pukul 09.05 WIB).

[8] A. Rachmat Eki. "Studi Awal Pembuatan Komposit $\mathrm{FeTiO}_{3}-\mathrm{Al}$ dengan Teknik Metalurgi Serbuk untuk bahan Filter Gas", Tugas Akhir Metalurgi-UNJANI, 2009.

[9] J. W. Xie, Y. Y. Zhao dan J. J. Dunkley. "Effects of processing conditions on powder particle size and morphology in centrifugal atomisation of tin", (2003).

[10] https://www.scribd.com/doc/150107164/E LEKTROKIMIA (diakses pada tanggal 21 november 2017 pukul 07.19 WIB). 